\title{
Hormonal Regulation of Lipolysis and \\ Phosphorylase Activity in Human Fat Cells
}

\author{
JaY Moskowitz and John N. FAIN \\ From the Division of Biological and Medical Sciences, Brown University, \\ Providence, Rhode Island 02912
}

\begin{abstract}
A в S T R A C T Prostaglandin $\mathrm{E}_{1}\left(\mathrm{PGE}_{1}\right)$ at a concentration of $1 \mathrm{ng} / \mathrm{ml}$ antagonized theophylline, and norepinephrine induced release of glycerol and free fatty acids (FFA) in human fat cell preparations. Insulin at higher doses also inhibited theophylline-stimulated lipolysis. The $N_{6}$-2-0'dibutyryl derivative of cyclic adenosine monophosphate (DCAMP) stimulated lipolysis. Prostaglandin $E_{1}$ did not significantly inhibit the lipid mobilizing effects of DCAMP. Changes in glycogen phosphorylase activity after treatment with theophylline, norepinephrine, DCAMP, and $\mathrm{PGE}_{1}$ paralleled those of lipolysis. These results suggest that in man as in experimental animals lipolysis and phosphorylase activity are regulated through processes involving cyclic $A M P$ and that $P E_{1}$ appears to exert its antilipolytic effect in human fat cells, as in rat fat cells, by interfering at the level of adenyl cyclase with the accumulation of cyclic AMP.
\end{abstract}

\section{INTRODUCTION}

Lipid mobilization is primarily controlled by the rate of hydrolysis of the triglyceride stores of the fat cells of adipose tissue (1). Catecholamines stimulate free fatty acid (FFA) mobilization by activating adenyl cyclase, an enzyme involved in the production of $3^{\prime} .5^{\prime}$-cyclic adenosine monophosphate (AMP) (2). Methylxanthines are thought to potentiate lipolysis by inhibiting the cyclic nucleotide phosphodiesterase, the enzyme responsible for the distruction of $3^{\prime}, 5^{\prime}$-cyclic AMP (2, $3)$. The accumulation of the cyclic AMP presumably activates an inactive lipase which hydrolyzes triglycerides (4).

A preliminary report of these studies was presented at the December 1968 meeting of the Eastern Section of the American Federation for Clinical Research.

Received for publication 30 January 1969 and in revised form 13 May 1969.
Prostaglandin $E_{1}\left(\mathrm{PGE}_{1}\right)$ has been found to antagonize the in vitro stimulation by catecholamines and theophylline of lipolysis in rat adipose tissue (5-7). In man, the infusion of $\mathrm{PGE}_{\mathbf{1}}$ causes a rise in plasma free fatty acids (8). It was originally reported that $\mathrm{PGE}_{1}$ in vitro reduced basal lipolysis, but not that due to catecholamines in human adipose tissue (9). Recently Carlson and Hallberg (10) were able to show partial inhibition of catecholamine-induced lipolysis by $\mathrm{PGE}_{1}$ in subcutaneous and omental human adipose tissue slices.

The present studies were designed to test the possibility that cyclic AMP is involved in human fat cell lipolysis and glycogenolysis. These studies suggest that the actions of prostaglandin $E_{1}$, methylxanthines, catecholamines, and dibutyryl cyclic AMP (DCAMP) on these processes in human fat cells are quite similar to the effects which have been observed with fat cells from rats.

\section{METHODS}

Human adipose tissue was obtained during the course of abdominal surgery. Severely obese patients and those with diabetes and jaundice were excluded. Preparative treatment included an overnight fast and medication with Nembutal, Demerol, and scopolamine. Patients were given either spinal or general anesthesia or both. Adipose tissue samples were usually obtained from the abdominal wall just before closure of the wound. Within $5 \mathrm{~min}$ after removal the tissue was placed in $0.9 \%$ saline $\left(37^{\circ} \mathrm{C}\right)$ and cut into small pieces. Connertive tissue was removed and the tissue was incubated in saline for several minutes at $37^{\circ} \mathrm{C}$. The pieces of adipose tissue were then removed and placed in plastic bottles for collagenase digestion. Rat white fat cells were isolated from the parametrial and periovarian adipose tissue of immature female rats (Sprague-Dawley, CD, Charles River Breeding Laboratories) The rats were fed ad lib. on laboratory chow and sacrificed by decapitation.

The cells were isolated by a modification of the procedure of Rodbell (11) in $4 \%$ albumin solution (bovine fraction $\mathrm{V}$ albumin powder obtained from the Pentex, Inc., Kankakee, Ill. (P-55) (Fig. 4 only) or the Armour Pharmaceutical Co., Chicago, Ill.) (A-27) made up fresh daily 


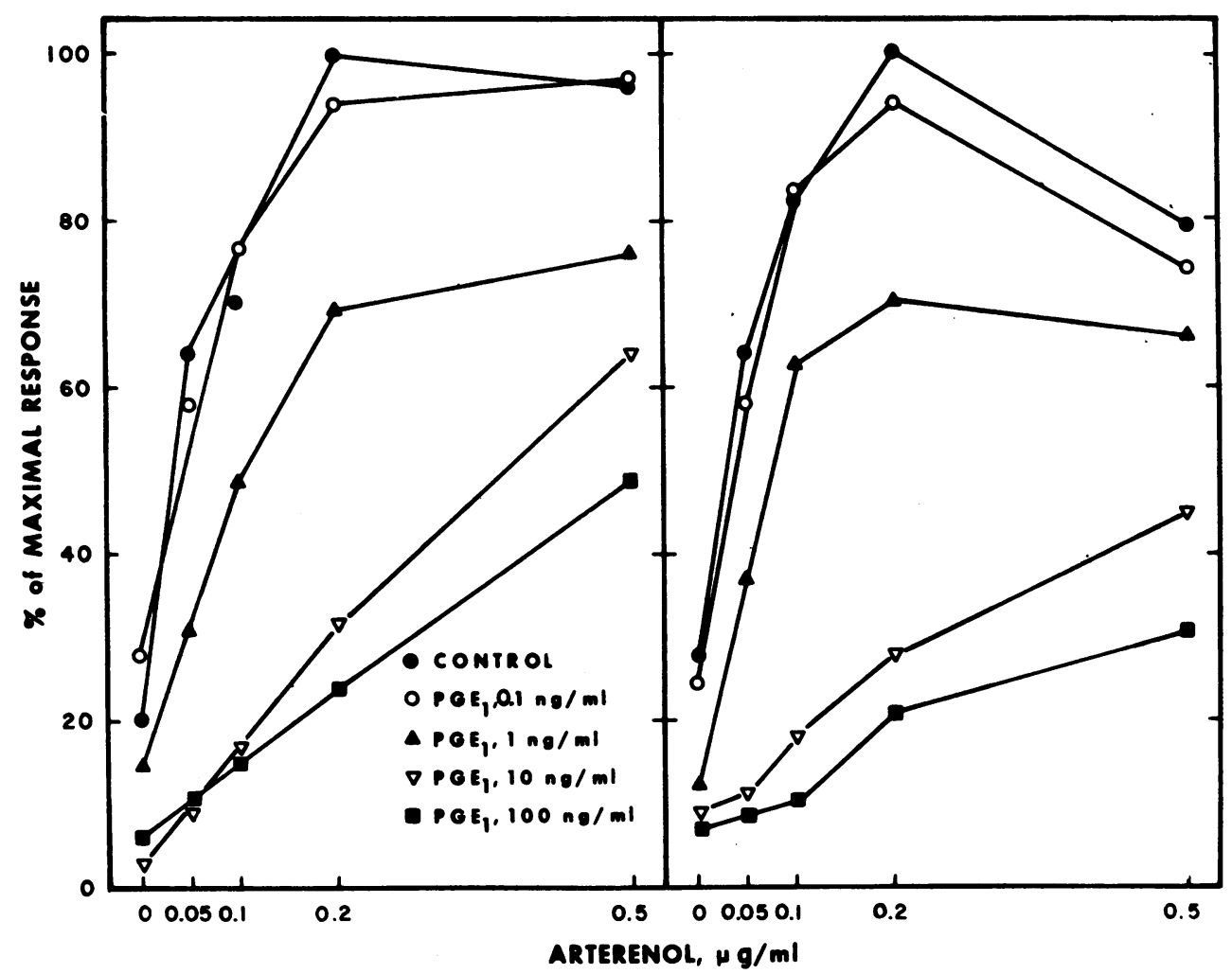

FIGURE 1 Inhibition by prostaglandin $E_{1}$ of the lipolytic action of norepinephrine on isolated human fat cells. Free fat cells ( $35.6 \mu$ moles triglyceride/flask) were incubated for $4 \mathrm{hr}$ in 1.5 $\mathrm{ml}$ of $4 \%$ albumin (A-27) in buffer without added glucose. Prostaglandin $E_{1}$ and norepinephrine bitartrate (arterenol) were added at the start of the incubation. Each point is the mean of eight paired experiments. Prostaglandin $E_{1}$ at concentrations of $1 \mathrm{ng} / \mathrm{ml}$ or greater significantly inhibited the increase in lipolysis due to all doses of arterenol $(P<0.05$ by paired comparisons).

in phosphate buffer. The phosphate buffer contained: $\mathrm{NaCl}$, 129 mmoles/liter $\mathrm{KCl} 5.15$ mmoles/liter; $\mathrm{CaCl}_{2} \quad 1.39$ mmoles/liter; MgSO, 1.4 mmoles/liter; and $\mathrm{Na}_{2} \mathrm{HPO}_{4}, 10$ mmoles/liter. The $\mathrm{pH}$ was adjusted to 7.4 with $\mathrm{NaOH}$. Pieces of adipose tissue were placed in 1-ounce plastic bottles containing $3 \mathrm{ml}$ of $4 \%$ albumin in buffer and $1.5 \mathrm{mg}$ of crude bacterial collagenase (Clostridium histolyticum, Worthington Biochemical Corp., Freehold, N. J.), incubated for $1 \mathrm{hr}$ at $37^{\circ} \mathrm{C}$ in a Dubnoff metabolic shaker and then filtered through nylon chiffon to remove any remaining stromal material and undigested adipose tissue. The separated cells were washed three times in $1 \%$ albumin in buffer and resuspended in $4 \%$ albumin in buffer for incubation studies.

In all studies the fat cells were incubated in $17 \times 100$ $\mathrm{mm}$ plastic culture tubes. Initial control values were obtained on cells incubated for $5 \mathrm{~min}$. The values for glycerol and fatty acid release in each experiment were the average of duplicate tubes, except for studies in which phosphorylase activity was measured which were done in quadruplicate, using pooled fat cells obtained from a single patient or three rats. All experiments were replicated from five to eight times and each replication was done on a separate day. Glycerol was determined on either a 50 or $100 \mu l$ aliquot of the medium by a micromodification of the enzymatic procedure of Vaughan (12) in which diphosphopyridine nucleotide (DPNH) formation was measured with a filter fluorometer (American Instrument Co. Inc., Silver Springs, Md.) Free fatty acids were determined on the remainder of the incubation medium by a modification of the procedure of Dole and Meinertz (13) in which hexane was substituted for heptane. Phosphorylase activity was determined by a modification of the procedure of Diamond and Brody (14). After the incubation period, the fat cells from the four tubes for each point were separated by centrifugation from the albumin-containing medium, resuspended in $2 \mathrm{ml}$ of cold $\left(0^{\circ}-5^{\circ} \mathrm{C}\right) 50 \mathrm{~mm}$ Tris buffer $(\mathrm{pH} 6.8)$ containing $1 \mathrm{mM}$ ethylenediaminetetraacetate (EDTA), $20 \mathrm{~mm} \mathrm{NaF}$, and $0.3 \%$ albumin, and homogenized immediately with a Potter-Elvehjem homogenizer (Teflon pestle). After centrifugation at $26,000 \mathrm{~g}$ for $10 \mathrm{~min}$ at $0^{\circ} \mathrm{C}, 0.2 \mathrm{ml}$ aliquots of the infranatant, the soluble layer between the pellet and the fat cake, were incubated in $50 \mathrm{~mm}$ Tris buffer $\mathrm{pH} 6.8,0.4 \%$ glycogen, $10 \mathrm{~mm}$ glucose-1-phosphate, $1 \mathrm{~mm}$ EDTA, $20 \mathrm{~mm}$ $\mathrm{NaF}$, and $0.3 \%$ albumin in a total volume of $1 \mathrm{ml}$ in the presence and absence of $1 \mathrm{mM}$ AMP. The addition of $5^{\prime}$-AMP 
FFA RELEASE

\section{GLYCEROL RELEASE}

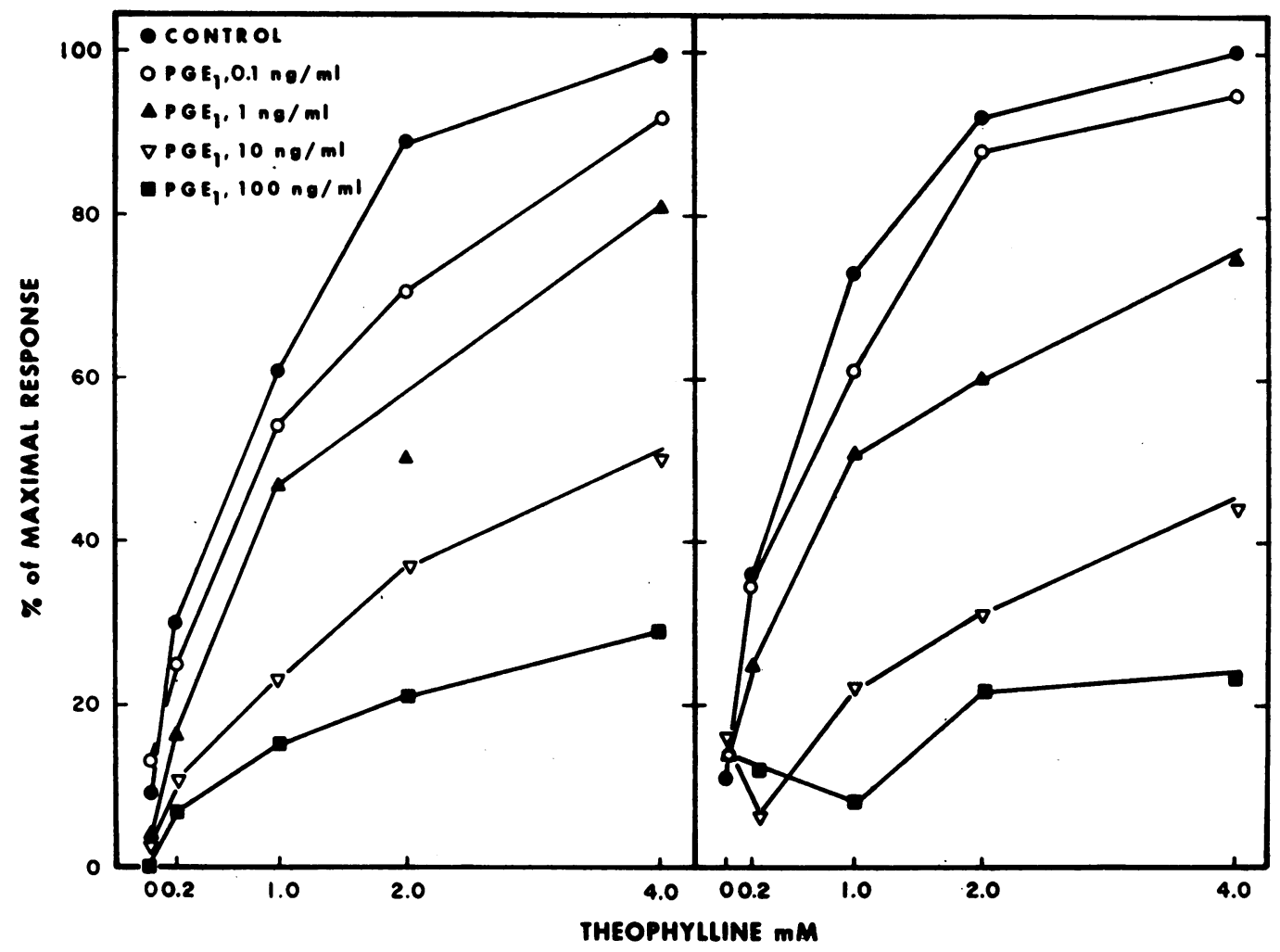

FIGURE 2 Inhibition by prostaglandin $E_{1}$ of the lipolytic action of theophylline on isolated fat cells. Free fat cells ( $49.3 \mu$ moles triglyceride/flask) were incubated for $4 \mathrm{hr}$ in $1.5 \mathrm{ml}$ of $4 \%$ albumin (A-27) in buffer without added glucose. Prostaglandin $E_{1}$ and theophylline were added at the start of the incubation. Each point is the mean of six paired experiments. Prostaglandin $E_{1}$ at concentrations of $1 \mathrm{ng} / \mathrm{ml}$ or greater significantly inhibited the increase in lipolysis due to all doses of theophylline $(P<0.05$ by paired comparisons).

increased the activity of the phosphorylase. The increment was, however, the same in the presence of lipolytic and antilipolytic agents. Vaughan (15), working with rat adipose tissue, reported that the effect of $5^{\prime}$-AMP does not seem to be related to prior treatment of the tissue. At present there are no quantitative data available concerning the dependence of various forms of adipose tissue phosphorylase on $5^{\prime}$-AMP. The rate of production of inorganic phosphate was constant for $30 \mathrm{~min}$ in both the presence and absence of AMP. No phosyphorylase was detected if glycogen was omitted from the incubation medium. The dependence on glycogen in the assay system indicates that organic phosphate formation is due to phosphorylase activity rather than nonspecific phosphatase activity.

Prostaglandin $E_{1}$ was a gift of Dr. John E. Pike (The Upjohn Co., Kalamazoo, Mich.) ; L-norepinephrine bitartrate (arterenol), theophylline, dibutyryl cyclic AMP (DCAMP), and AMP were obtained commercially. Stock solutions of these agents were stored at $-15^{\circ} \mathrm{C}$. In the presentation of the data, the arithmetic mean is used. However, the significance of the differences between the various experimental pairs was determined by the use of the Student's $t$ test (16) on the logarithms of the paired differences. The distribution of the data was not normal, as is often the case in biological systems, and for data of this kind the logarithms are distributed more normally (16). The original ranges and means were nearly proportional, but after logarithmic transformations the ranges were almost equal and uncorrelated with the means.

\section{RESULTS}

Low concentrations of norepinephrine bitartrate (arterenol) markedly stimulated lipolysis by human fat cells (Fig. 1). Maximal stimulation of lipolysis was seen with $0.2 \mu \mathrm{g} / \mathrm{ml}$ of arterenol and a higher concentration actually gave somewhat lower lipolysis as based on glycerol release.

As little as $1 \mathrm{ng} / \mathrm{ml}$ of prostaglandin $E_{1}$ was able to inhibit lipolysis due to all concentrations of arterenol (Fig. 1). Maximal inhibition of the lipolytic action of arterenol was obtained at $\mathrm{PGE}_{1}$ concentration of 100 $\mathrm{ng} / \mathrm{ml}$.

The effect of PGE 1 on the theophylline-induced lipolysis was similar to that seen with norepinephrine (Fig. 
2). The average increase in glycerol release due to the highest concentration of theophylline in the studies shown in Fig. 2 was $12.5 \mu$ moles $/ \mathrm{mmole}$ triglyceride as contrasted to $10.8 \mu$ moles $/ \mathrm{mmole}$ triglyceride in the presence of norepinephrine (Fig. 1). The results in both figures are shown as the per cent of maximal response, since the per cent differences varied much less between experiments than the actual differences due to $\mathrm{PGE}_{1}$. Lipolysis was significantly inhibited, at all doses of theophylline and arterenol, in the presence of $1 \mathrm{ng} / \mathrm{ml}$ or more of PGE. Insulin had an antilipolytic action on theophylline-induced lipolysis (Fig. 3). However, the effects of insulin were more variable than those of $\mathrm{PGE}_{1}$, and only the effect of $100 \mu \mathrm{U}$ of insulin/ml was statistically significant.

The addition of the dibutyryl derivative of cyclic AMP, $N^{\circ}-2-0^{\circ}$-dibutyryl cyclic AMP (DCAMP) increased lipolysis in the human cells (Fig. 4). In experiments with isolated rat fat cells significant increases in DCAMP-stimulated lipolysis were achieved with lower concentrations in human cells than in rat fat cells. The maximal response per millimole of triglyceride was much greater, however, in the rat fat cells. The effects of PGE 1 on the DCAMP-stimulated lipolysis are given in Table I. While the effects of high doses of theophylline were markedly inhibited by $100 \mathrm{ng} / \mathrm{ml}$ of $\mathrm{PGE}_{1}$ (64\% inhibition) $\mathrm{PGE}_{1}$ had little or no effect on DCAMP-stimulated lipolysis.

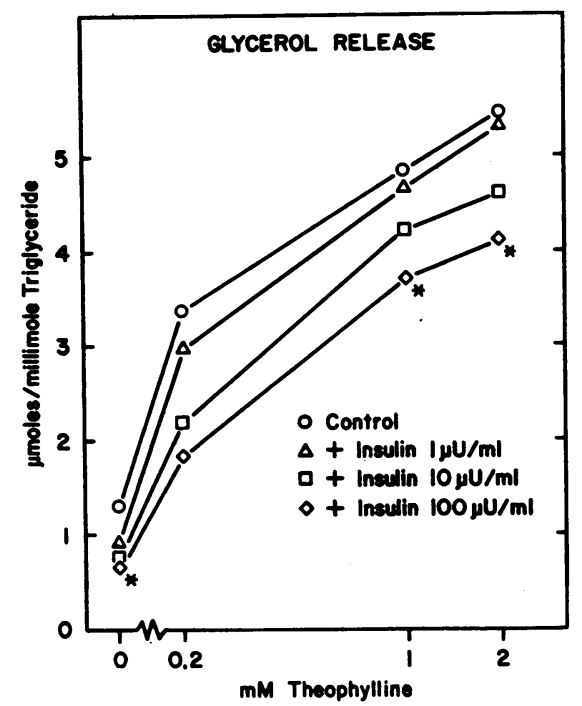

FIGURE 3 The effect of insulin on the lipolytic action of theophylline in isolated human fat cells. Free fat cells (45.0 $\mu$ moles triglyceride/flask) were incubated for $4 \mathrm{hr}$ in $1.5 \mathrm{ml}$ of $4 \%$ albumin (A-27). Theophylline and insulin were added at the start of the incubation. Each point is the mean of six paired experiments. Significant effects of insulin are shown by asterisks ( $P<0.05$ by paired comparisons).

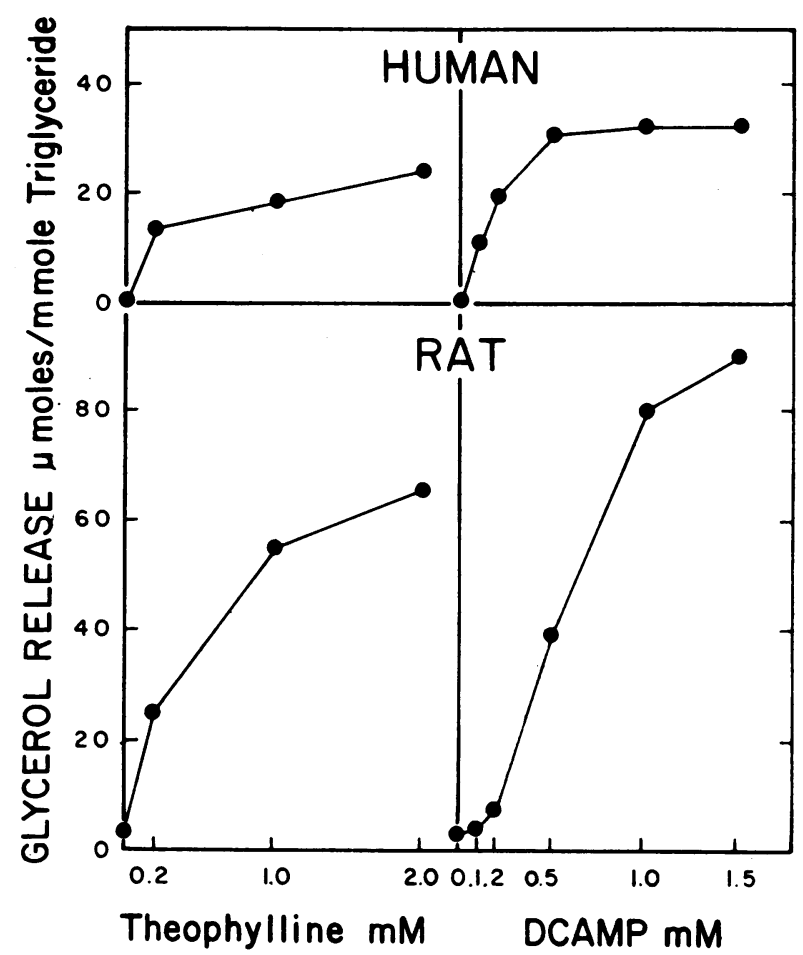

FIgURE 4 Sensitivity of human fat cells to lipolytic action of dibutyryl cyclic AMP as compared to rat fat cells. Free rat fat cells (15.7 $\mu$ moles triglyceride/flask) and human fat cells (15.8 $\mu$ moles triglyceride/flask) were incubated for $4 \mathrm{hr}$ in $1.5 \mathrm{ml}$ of $4 \%$ albumin (P-55) without added glucose. Dibutyryl cyclic AMP (DCAMP) and theophylline were added at the start of the incubation period. Each point is the mean of five paired experiments. The rat and human cells were incubated at the same time under identical conditions.

To measure the effects of $\mathrm{PGE}_{1}$ on a parameter of cyclic AMP action other than lipolysis, we measured glycogen phosphorylase activity in extracts of the isolated fat cells. Theophylline and norepinephrine increased both phosphorylase activity and lipolysis in the human fat cells (Table II). PGE 1 inhibited the increase in phosphorylase activity due to norepinephrine and theophylline, both in the presence and absence of AMP (Table II). The total lipolytic response due to these agents were lower than that in our other studies because of the large amount of cells (87.1 $\mu$ moles triglyceride/flask) needed to obtain detectable phosphorylase activity. $\mathrm{PGE}_{1}$ inhibited both phosphorylase activity and glycerol release in the theophylline and arterenol-stimulated cells.

The effects of PGE 1 on DCAMP-stimulated lipolysis and phosphorylase activity were also examined ( $\mathrm{Ta}$ ble III). Both phosphorylase activity and lipolysis were stimulated by the addition of DCAMP. Prostaglandin $E_{1}$ did not affect the stimulation of lipolysis and 
TABLE I

Failure of Prostaglandin $E_{1}$ to Inhibit the Lipolytic Action of Dibutyryl Cyclic AMP on Human Fat Cells

\begin{tabular}{|c|c|c|c|c|}
\hline \multirow[b]{2}{*}{ Additions } & \multicolumn{2}{|c|}{ Free fatty acid release } & \multicolumn{2}{|c|}{ Glycerol release } \\
\hline & $\begin{array}{c}\text { Increment } \\
\text { due to } \\
\text { lipolytic } \\
\text { agent }\end{array}$ & $\begin{array}{l}\text { Inhibition } \\
\text { by } \text { PGE }_{1}\end{array}$ & $\begin{array}{l}\text { Increment } \\
\text { due to } \\
\text { lipolytic } \\
\text { agent }\end{array}$ & $\begin{array}{l}\text { Inhibition } \\
\text { by } \text { PGE }_{1}\end{array}$ \\
\hline & $\begin{array}{c}\text { umoles } / \text { mmole } \\
\text { triglyceride }\end{array}$ & $\%$ & $\begin{array}{l}\text { umoles/mmole } \\
\text { triglyceride }\end{array}$ & $\%$ \\
\hline DCAMP & 24.5 & $5 \pm 3$ & 12.5 & $2 \pm 3$ \\
\hline $\begin{array}{l}\text { Theophylline } \\
4 \text { mmoles/liter }\end{array}$ & 17.0 & $61 \pm 13$ & 8.0 & $64 \pm 1$ \\
\hline
\end{tabular}

Free fat cells (36 $\mu$ moles triglyceride/tube) were incubated for $4 \mathrm{hr}$ in $1.5 \mathrm{ml}$ of $4 \%$ albumin with the additions added at the start of incubation period. The values are the means of 5 paired experiments $\pm \mathrm{SE}$. Basal release of fatty acid and glycerol were 13 and $1.4 \mu$ moles $/$ mmole triglyceride, respectively. $\mathrm{PGE}_{1}$ concentration, when present, was $100 \mathrm{ng} / \mathrm{ml}$. $\mathrm{PGE}_{1}$ =prostaglandin $\mathrm{E}_{1} ; \mathrm{AMP}=$ adenosine monophosphate; DCAMP = dibutyryl cyclic AMP.

phosphorylase activity by DCAMP while that of theophylline was greatly reduced by $P G E_{1}$.

\section{DISCUSSION}

Previous investigators of human adipose tissue lipolysis have reported a poor response of this tissue to catecholamines (10, 17-19). Galton and Bray (20) have recently demonstrated that isolated fat cells respond better than tissue to large quantities of epinephrine. The isolated fat cells preparations used in this study responded to low concentrations of catecholamines, since $10^{-7} \mathrm{M}$ norepinephrine significantly increased lipolysis.

Human adipose tissue lipolysis appears to be very sensitive to the antilipolytic agent, prostaglandin $E_{1}$. Carlson and Hallberg (10) have reported an antilipolytic effect of PGE 1 on omental and (less often) subcutaneous adipose tissue lipolysis stimulated by norepinephrine. A large dose of $P E_{1} 100 \mathrm{ng} / \mathrm{ml}$ was utilized to inhibit the hormone-stimulated lipolysis and this inhibition was achieved in only two of the four subcutaneous specimens examined (10). The present studies indicate that free fat cell preparations are very sensitive to $\mathrm{PGE}_{1}$ since $1 \mathrm{ng} / \mathrm{ml}$ inhibited norepinephrine-induced lipolysis (Fig. 1). The responsiveness of the human fat cell preparations to norepinephrine and $\mathrm{PGE}_{1}$ are similar to the results of previous observations with rat fat cells (21).

Theophylline has not been utilized as a lipolytic agent with human fat cell preparations. In our hands, the maximal rate of lipolysis in human fat cells seen with theophylline was about the same as that due to catecholamines. Low doses of theophylline $(0.2 \mathrm{mmole} / \mathrm{liter})$
TABLE II

Inhibition by Prostaglandin $E_{1}$ of the Activation of Lipolysis and Phosphorylase by Arterenol and Theophylline

$$
\text { + The- }
$$

Basal + Arterenol ophylline

Phosphorylase activity in the presence of $1 \mathrm{mM}$ AMP umoles phosphate/mmole triglyceride

No additions

$4.12 \quad 6.92$

$$
6.72
$$

3.52

5.32

Increment due to

$-0.60$

$-1.60^{*}$

4.92

Phosphorylase activity in the absence of AMP umoles phosphate/mmole triglyceride

No additions $\begin{array}{lll}1.64 & 4.80 & 3.72\end{array}$

Prostaglandin $\mathrm{E}_{1}$

1.16

2.60

2.20

Increment due to $\mathrm{PGE}_{1}$

$-0.48$

$-2.20^{*}$

$-1.52^{*}$

Glycerol release

No additions

Prostaglandin $E_{1}$

umoles glycerol/mmole triglyceride

Increment due to $\mathrm{PGE}_{1}$

$\begin{array}{rcr}2.87 & 4.05 & 4.49 \\ 2.86 & 2.90 & 3.10 \\ -0.01 & -1.15^{*} & -1.39^{*}\end{array}$

Human fat cells (87.1 $\mu$ moles triglyceride/flask) were incubated for $1 / 2 \mathrm{hr}$ in $1.5 \mathrm{ml}$ of $4 \%$ albumin in buffer without added glucose. Arterenol (norepinephrine bitartrate) 0.1 $\mu \mathrm{g} / \mathrm{ml}$, theophylline (1 mmole/liter), and prostaglandin $\left(\mathrm{PGE}_{1}\right)(100 \mathrm{ng} / \mathrm{ml})$ were added at the start of the incubation period. The values are shown as the means of 8 paired experiments. The increases due to arterenol and theophylline in the absence of $\mathrm{PGE}_{1}$ are significant $(\mathrm{P}<0.05)$.

* A significant effect of $\mathrm{PGE}_{1}$ is indicated, $\mathrm{P}<0.05$.

elicited a lipolytic response similar to $0.05 \mu \mathrm{g} / \mathrm{ml}$ norepinephrine. As was the case with catecholamines, extremely low doses of $\mathrm{PGE}_{1}$ (as low as $1 \mathrm{ng} / \mathrm{ml}$ ) were potent inhibitors of theophylline-stimulated lipolysis.

Few reports on insulin as an antilipolytic agent on human cell lipolysis have appeared except for that of Galton and Bray (20), who found the human fat cell response to insulin to be quite erratic. Although insulin at $1000 \mu \mathrm{U} / \mathrm{ml}$ decreased epinephrine-stimulated lipolysis, the difference was not significant (20). Burns and Langley (22) have more recently found epinephrine-stimulated lipolysis in human cells to be inhibited by low doses of insulin. We have also, like Galton and Bray (20), found the response of human cells to insulin quite erratic. However, the theophyllinestimulated lipolysis was significantly reduced with 100 $\mu \mathrm{U} / \mathrm{ml}$ insulin in our experiments.

Human cells have been shown to be sensitive to insulin as based on stimulation of glucose incorporation into $\mathrm{CO}_{2}$ and fatty acids (23). The sensitivity of the 
TABLE III

The Stimulation of Phosphorylase Activity and Lipolysis by Dibutyryl Cyclic AMP in Human Fat Cells

\begin{tabular}{|c|c|c|c|}
\hline Additions & Basal & $\begin{array}{l}\text { Increment due } \\
\text { to DCAMP }\end{array}$ & $P$ value \\
\hline \multicolumn{4}{|c|}{$\begin{array}{l}\text { Phosphorylase activity in the presence of } 1 \mathrm{mM} \text { AMP } \\
\text { umoles phosphate } / \text { mmole } \\
\text { triglyceride }\end{array}$} \\
\hline None & 5.76 & +4.40 & 0.01 \\
\hline $\mathrm{PGE}_{1}$ & 4.72 & +4.64 & 0.05 \\
\hline Theophylline & 9.32 & +0.68 & NS \\
\hline Theophylline $+\mathrm{PGE}_{1}$ & 6.16 & +2.96 & 0.01 \\
\hline \multicolumn{4}{|l|}{ Glycerol release } \\
\hline & \multicolumn{3}{|c|}{$\begin{array}{c}\text { umoles glycerol/mmole } \\
\text { triglycei ide }\end{array}$} \\
\hline None & 2.49 & +0.87 & 0.01 \\
\hline $\mathrm{PGE}_{1}$ & 2.34 & +0.56 & 0.01 \\
\hline Theophylline & 3.29 & +0.77 & 0.05 \\
\hline Theophylline $+\mathrm{PGE}_{1}$ & 2.46 & +0.89 & 0.01 \\
\hline
\end{tabular}

Free human fat cells (95.6 $\mu$ moles triglyceride/flask) were incubated for $1 / 2 \mathrm{hr}$ in $1.5 \mathrm{ml}$ of $4 \%$ albumin without added glucose. Dibutyryl cyclic AMP (0.25 mmole/liter), theophylline (1 mmole/liter), and prostaglandin $\mathrm{E}_{1}\left(\mathrm{PGE}_{1}\right)(100$ $\mathrm{ng} / \mathrm{ml}$ ) were present from the start of the incubation. The basal values and the increments due to the addition of DCAMP are shown as the means of 5 paired experiments. The increment due to DCAMP was not affected by PGE $_{1}$ either in the presence or absence of theophylline $(P<0.05$ by paired differences which is also used as the criteria for nonsignificant differences represented by NS).

cells appears to be reduced with age (23) and increased cell size (24). The variations in the antilipolytic effects of insulin in our studies may be due to high titers of insulin in the patients' plasma before excision of the tissue, since the patients in our studies received a glucose infusion during surgery.

Since both norepinephrine and theophylline are believed to increase the accumulation of cyclic AMP in the rat fat cell (2), we utilized the $N^{6}-2-0$-dibutyryl derivative of cyclic AMP (DCAMP) to see if it would stimulate lipolysis in the human fat cells. Our data indicate that human adipocytes respond to DCAMP and are more sensitive to low doses of this compound than are the rat fat cells. However, high doses of DCAMP gave a greater stimulation of lipolysis in rat adipocytes than in human cells. The reason for the 5-fold greater sensitivity of human fat cells lipolysis to $0.1 \mathrm{~mm}$ DCAMP is not clear.

Prostaglandin $\mathrm{E}_{1}$ did not inhibit the lipolytic response of the human cells to DCAMP. This lack of effect would

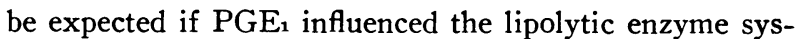
tem by interfering with the accumulation of cyclic AMP. Thus, PGE 1 should have no effect on the acti- vation of inactive lipase to active lipase or of glycogen phosphorylase by $3^{\prime}, 5^{\prime}$-cyclic adenosine monophosphate. It has been suggested that $P_{1} E_{1}$ might activate the phosphodiesterase involved in degradation of cyclic AMP (25). This appears unlikely since DCAMP is degraded by the phosphodiesterase (26) which attacks cyclic AMP, and if $\mathrm{PGE}_{1}$ activates this enzyme it should have inhibited the action of DCAMP on human fat cells.

Prostaglandin $\mathrm{E}_{1}$ lowered the increases of phosphorylase activity and lipolysis due to the addition of norepinephrine and theophylline. These results confirm data from animal studies which concluded that $P_{1} E_{1}$ inhibited the activation of phosphorylase and lipase activity due to catecholamines (27).

From these studies it is evident that the human adipocyte preparation responds in a manner similar to rat fat cells when challenged with various lipolytic agents. Norepinephrine, theophylline, and dibutyryl cyclic nucleotide all stimulated both lipolysis and glycogenolysis. Insulin and prostaglandin $E_{1}$ reduce the stimulation of both processes by norepinephrine and theophylline but not by dibutyryl cyclic AMP. The data from the studies with PGE, support the hypothesis that cyclic AMP is involved in the activation of lipolysis and phosphorylase in human as in rat fat cells and that $\mathrm{PGE}_{1}$ probably acts to inhibit adenyl cyclase.

\section{ACKNOWLEDGMENTS}

The authors express their appreciation for the technical assistance of Doris Delekta and the Operating Room Staff of The Rhode Island Hospital.

This work was supported by U. S. Public Health Service Grant AM-10149 from the National Institute of Arthritis and Metabolic Diseases.

\section{REFERENCES}

1. Carlson, L. A., J. Boberg, and B. Högstedt. 1965. Some physiological and clinical implications of lipid mobilization from adipose tissue. In Handbook of Physiology, Section 5. A. F. Renold and G. F. Cahill, Jr., editors. The Williams \& Wilkins Company, Baltimore. 625 .

2. Butcher, R. W., R. J. Ho, H. C. Meng, and E. W. Sutherland. 1965. Adenosine 3',5'-monophosphate in biological materials. II. The measurement of adenosine $3^{\prime}, 5^{\prime}$-monophosphate in tissue and the role of the cyclic nucleotide in the lipolytic response of fat to epinephrine. J. Biol. Chem. 240: 4515.

3. Hynie, S., G. Krishna, and B. B. Brodie. 1966. Theophylline as a tool in studies of the role of cyclic adenosine $3^{\prime}, 5^{\prime}$-monophosphate in hormone-induced lipolysis. $J$. Pharmacol. Exp. Ther. 153: 90.

4. Rizack, M. A. 1965. Hormone-sensitive lipolytic activity of adipose tissue. In Handbook of Physiology, Section 5. A. E. Renold and G. F. Cahill, Jr., editors. The Williams \& Wilkins Company, Baltimore. 309.

5. Steinberg, D., M. Vaughan, P. J. Nestel, and S. Bergström. 1963. Effects of prostaglandin $E_{1}$ opposing those of catecholamines on blood pressure and on triglyceride 
breakdown in adipose tissue. Biochem. Pharmacol. 12: 764.

6. Fain, J. N. 1968. Antilipolytic effect of prostaglandin $\mathrm{E}_{1}$ on free fat cells. In Prostaglandin Symposium of the Worcester Foundation for Experimental Biology. P. W. Ramwell, and J. E. Shaw, editors. Interscience Publishers Inc. New York. 67.

7. Stock, K., A. Aulich, and E. Westermann. 1968. Studies on the mechanism of antilipolytic action of prostaglandin $E_{1}$. Life Sci. 7: 113.

8. Bergström, S., L. A. Carlson, L. Ekelund, and I. Orö. 1965. Cardiovascular and metabolic response to infusions of prostaglandin $E_{1}$ and to simultaneous infusions of noradrenaline and prostaglandin $\mathrm{E}_{1}$ in man. Acta Physiol. Scand. 64: 332.

9. Carlson, L. 1965. Inhibition of the mobilization of free fatty acids from adipose tissue. Ann. N.Y. Acad. Sci. 131: 119.

10. Carlson, L. A., and D. Hallberg. 1968. Basal lipolysis and effects of norepinephrine and prostaglandin $E_{1}$ on lipolysis in human subcutaneous and omental adipose tissue. J. Lab. Clin. Med. 71: 368.

11. Rodbell, M. 1964. The metabolism of isolated fat cells. I. Effects of hormones on glucose metabolism and lipolysis. J. Biol. Chem. 239: 375.

12. Vaughan, M. 1962. The production and release of glycerol by adipose tissue incubated in vitro. J. Biol. Chem. 237: 3354.

13. Dole, V. P. and H. Meinertz. 1960. Micro-determination of long-chain fatty acids in plasma and tissues. J. Biol. Chem. 235: 2595.

14. Diamond, J., and T. M. Brody. 1965. Phosphorylase activity in rat uterus after catecholamine administration. Biochem. Pharmacol. 14: 7.

15. Vaughan, M. 1960. Effect of Hormones on Phosphorylase Activity in Adipose Tissue. J. Biol. Chem. 235: 3049.

16. Snedecor, G. W. 1956. Statistical Methods. Iowa State University Press, Ames. 5th edition. 45.
17. Hamosh, M., P. Hamosh, J. A. Bar-Maor, and H. Cohen. 1963. Fatty-acid metabolism by human adipose tissues. J. Clin. Invest. 42: 1648.

18. Björntorp, P. 1964. The fatty acid release and lipolysis of human subcutaneous adipose tissue in vitro. Metabolism (Clin. Exp.). 13: 1318.

19. Mosinger, B., E. Kuhn, and V. Kujalova. 1965. Action of adipokinetic hormones on human adipose tissue in vitro. J. Lab. Clin. Med. 66: 380.

20. Galton, D. J., and G. A. Bray. 1967. Studies on lipolysis in human adipose cells. J. Clin. Invest. 46: 621.

21. Fain, J. N. 1967. Adrenergic blockade of hormone induced lipolysis in isolated fat cells. Ann. N.Y. Acad. Sci. 139: 879.

22. Burns, T. W., and P. Langley. 1968. Observations on lipolysis with isolated adipose tissue cells. J. Lab. Clin. Med. 72: 813.

23. Gries, F. A., and J. Steinke. 1967. Comparative effects of insulin on adipose tissue segments and isolated fat cells of rat and man. J. Clin. Invest. 46: 1413.

24. Salans, L. B., J. L. Knittle, and J. Hirsch. 1968. The role of adipose cell size and adipose tissue insulin sensitivity in carbohydrate intolerance of human obesity. J. Clin. Invest. 47: 153.

25. Mühlbachova, E., A. Sólyom, and L. Puglisi. 1967. Investigations on the mechanism of prostaglandin $E_{1}$ antagonism to norepinephrine and theophylline-induced lipolysis. Eur. J. Pharmacol. 1 : 321.

26. Blecher, M., N. S. Merlino, and J. T. Ro'Ane. 1968. Control of the metabolism and lipolytic effects of cyclic $3^{\prime}, 5^{\prime}$-adenosine monophosphate in adipose tissue by insulin, methyl xanthines and nicotinic acid. J. Biol. Chem. 243: 3973.

27. Steinberg, D., M. Vaughan, P. J. Nestel, O. Strand, and S. Bergström. 1964. Effects of the prostaglandins on hormone-indured mobilization of free fatty acids. J. Clin. Invest. 43: 1533. 